Jurnal Professional FIS UNIVED Vol. 3 No.1 Juni 2016

\title{
PENINGKATAN PENGUNJUNG PADA HYPERMART MELALUI IKLAN DI HARIAN RAKYAT BENGKULU
}

\author{
Oleh: \\ LINDA IRMAWATI, MARIDA SARININGSIH, SYISVA NURWITA \\ Program Studi Ilmu Komunikasi Fakultas Ilmu-Ilmu Sosial Unived Bengkulu
}

\begin{abstract}
ABSTRACK
Advertising has become a hope for the majority of companies that want their products embedded in the hearts of consumers. If an ad is not likely to have a major influence on the behavior of consumers, the advertising effectiveness is doubtful. The purpose of this study was to determine the increasing number of visitors at Hypermart Bengkulu through ads in Rakyat Bengkulu daily newspapers. This study used qualitative methods, that's research that produces descriptive data in the form of words written or spoken of those that can be observed. Informants in this study were divided into two groups, namely the key informants consisting of 3 persons and key informants consisting of 4 people. The main theory used in this research was EPIC theory. The results in this study was, one element of the EPIC theory, namely is not going well because not every visitor read or subscribe to the Rakyat Bengkulu newspaper, so it effects on the increasing number in visitors at Hypermart Bengkulu.
\end{abstract}

Keywords: increasing, buyers, advertising, hypermart

\section{PENDAHULUAN}

Era globalisasi telah berimplikasi pada terbukanya peluang sekaligus tantangan bagi dunia usaha. Adapun salah satu tantangan terbesar dalam dunia usaha tersebut adalah meningkatnya persaingan antar perusahaan dalam mencari dan mempertahankan pelanggan agar tetap menggunakan roduk-produk yang mereka hasilkan. Karena itu, sangat penting bagi perusahaan untuk mampu menerapkan strategi komunikasi pemasaran yang efektif agar calon konsumen mampu mengetahui keberadaan dan keunggulan produk-produk tersebut. Dalam konteks ini, perusahaan harus berusaha untuk menyampaikan informasi dengan jelas dan membingkainya semenarik mungkin untuk menarik perhatian calon konsumen atau calon pelanggan.

Salah satu cara paling efektif untuk menginformasikan produk kepada calon konsumen atau calon pelanggan adalah melalui iklan. Melalui iklan produsen dapat menyampaikan kelebihan atau kekurangan produk. Iklan cenderung dapat menarik konsumen untuk melakukan pembelian terhadap suatu produk (Handoyo, 2004). Oleh karena itu, selain bersifat informati, iklan juga dibuat secara persuasive. Iklan telah menjadi harapan bagi sebagian besar perusahaan yang ingin produknya melekat di hati konsumennya. Pemanfaatan media dalam iklan telah memungkinkannya menjadi sarana paling efektif dan efisien untuk meraih konsumen dalam jumlah besar yang tersebar secara geografis. Selain digunakan untuk membangun kesan jangka panjang dan memicu penjualan produk dengan cepat, iklan diharapkan menjadi faktor pemicu utama yang mempengaruhi perilaku pembelian konsumen. Oleh karena itu, keefektifan iklan akan diragukan bila iklan 
tersebut tidak dapat mempengaruhi konsumen untuk membeli suatu produk. Pentingnya penggunaan iklan tak hanya dimanfaatkan oleh perusahaan-perusahaan berskala nasional. Pedagang-pedagang kecil dan perusahaan berskala multinasional juga mengandalkan iklan dan promosi untuk menjunjung pemasaran produk dan jasa mereka kepada masyarakat (Rusmanto, 2010). Pemasangan iklan pada media perlu penyesuaian dan pemilihan dengan tepat agar tidak menjadi salah sasaran terhadap konsumen yang hendak dituju (Widodo, 2011).

Pengunaan iklan sebagai media untuk menginformasikan produk-produk yang dijual juga dilakukan oleh perusahaan Hypermart. Perusahaan ini menggunakan media iklan di harian Rakyat Bengkulu. Berdasarkan pra-penelitian, diketahui bahwa pemilihan media cetak dilakukan dengan pertimbangan bahwa media tersebut dianggap lebih efektif untuk menarik pengunjung, diharapkan pengunjung akan mengetahui, membaca dan melihat produk yang ditawarkan. Selanjutnya konsumen akan memperhatikan, memahami, menafsirkan dan merespon iklan tersebut pada akhirnya menimbulkan niat untuk melakukan pembelian.

Dengan bahasa iklan yang dibuat menarik mungkin, pesan yang direkonstruksi diharapkan diterima khalayak untuk menjadi sebuah pemikiran dan perubahan tingkah laku yang berefek pada perubahan perilaku konsumen misalnya pola hidup yang selalu bermewah-mewah. Selain dari sisi produsen, dari hasil pra penelitian diketahui bahwa konsumen juga menyatakan pentingnya iklan dalam menginformasikan produk-produk yang dijual perusahaan.

Masing-masing media cetak memiliki kalangan pembaca tersendiri, Karena itu pihak perusahaan harus cermat dalam memilih media cetak yang akan digunakan sebagai sarana untuk mempromosikan produk/jasanya (Suriadi, 2010). Pada Hypermart, iklan di harian Rakyat Bengkulu merupakan media promosi yang dilakukan untuk menarik pembeli karena pelanggan langsung bisa mengetahui apa saja yang sedang dipromosikan, namun kendala pada iklan ini hanya sebagian saja yang mengetahui adanya promosi tersebut karena tingkat membaca koran harian rakyat bengkulu masyarakat masih sangat rendah serta sebarannya juga hanya pada kalangan tertentu saja. Sejalan dengan hal tersebut, maka dapatlah dikatakan bahwa iklan merupakan salah satu sarana penunjang bagi perusahaan di dalam mencapai tujuannya yaitu meraih lebih banyak calon pembeli dan pelanggan dengan biaya yang lebih rendah, dan dalam waktu yang lebih singkat. Sedangkan pengaruhnya, lebih lama melekat pada ingatan masyarakat. Iklan yang baik tidak hanya mampu menggugah, dan menarik pengunjung sehingga terdorong kearah tindakan pembelian, namun juga dapat memberikan keuntungan-keuntungan yang lain kepada perusahaan.

Seperti yang diketahui bahwa betapa iklan begitu mempengaruhi pengunjung dalam membeli barang atau jasa yang dihasilkan oleh suatu perusahaan, dengan demikan secara tidak langsung iklan tersebut sudah efektif. Namun pada kenyataannya, tidaklah semua iklan yang dapat menjalankan fungsi dan tujuannya sebagaimana yang diharapkan. Hal ini dikarenakan, masyarakat juga mempunyai pandangan dan penilaian sendiri-sendiri akibat dari berbagai pengaruh lain terhadap komunikator, pesan maupun media yang digunakan. Maka dari uraian diatas penulis tertarik untuk mengangkat judul "Peningkatan Pengunjung Pada Hypermart Melalui Iklan di Harian Rakyat Bengkulu"

\section{METODE PENELITIAN}

Jenis penelitian pada penelitian ini adalah penelitian kualitatif. Bodgan dan 
Tylor (dalam Moleong, 2002) mendefinisikan penelitian kualitatif sebagai penelitian yang menghasilkan data deskriptif dari orangorang dan perilaku yang dapat diamati. Penelitian kualitatif bertujuan memperoleh gambaran seutuhnya mengenai suatu hal menurut pandangan manusia yang diteliti.

Informan dalam penelitian ini dibagi kedalam dua kategori, yaitu informan kunci yang terdiri dari pegawai Hypermart Bengkulu, dan informan utama yang terdiri dari pengunjung Hypermart Bengkulu. Untuk mendapatkan kelengkapan informasi yang sesuai dengan fokus penelitian, peneliti menggunakan beberapa pengumpulan data, yaitu: observasi partisipan (pengamatan), yaitu pengamatan yang dilakukan secara sengaja, sistematis, mengenai fenomena sosial dengan gejala-gejala psikis untuk kemudian dilakukan pencatatan. (P.Joko Subagyo, 2011:63); wawancara Mendalam (interview), dan dokumentasi.

Komponen analisis data dalam penelitian ini meliputi beberapa tahap sesuai dengan yang dinyatakan Sugiyono (2008), yaitu: pengumpulan data, reduksi data, penyajian data, dan verifikasi atau penyimpulan data. Untuk keabsahan data, penulis menggunakan teknik triangulasi sumber. Adapun teknik triangulasi sumber adalah membandingkan dan mengecek balik derajat kepercayaan suatu informasi yang diperoleh melalui metode dan sumber data, yaitu wawancara dan observasi (Patton, 2011).

\section{HASIL PENELITIAN DAN PEMBAHASAN \\ Hasil Penelitian}

Pada hakikatnya, peningkatan pengunjung dapat terjadi pada setiap perusahaan apabila iklan yang disampaikan bisa menarik perhatian pengunjung serta dengan melakukan berbagai promosi. Pada penelitian ini diketahui bahwa ibu-ibu rumah tangga cenderung lebih berkunjung ke
Hypermart di banding yang lainnya dikarenakan tinggkat kebutuhan dalam rumah tangga. Orang dengan tanpa memandang jenis pekerjaan yang dijalaninya. Jika ditinjau dari aspek umur, kaum ibu-ibu rumah tangga yang berusia 23-35 tahun yang merupakan usia dimana keadaan kebutuhan masih kurang terkontrol dengan baik. Informan pada penelitian ini adalah pengunjung yang datang ke Hypermart yang menggunakan iklan di harian rakyat bengkulu, dengan pertimbangan bahwa syarat tersebut akan berimplikasi kepada informasi yang diperoleh, yaitu merumuskan penerapan peningkatan pengunjung melalui metode EPIC. Pengunjung yang menjadi informan merupakan ibu rumah tangga yang menggunakan iklan diharian rakyat Bengkulu, dengan rentang usia 27-45 tahun. Ibu rumah tangga yang menjadi informan terdiri dari 4 orang, Selain itu, peneliti juga mewawancarai staf Hypermart (misalnya departemen manager) untuk mengetahui kondisi Hypermart pada saat berlangsungnya promosi di iklan harian rakyat Bengkulu dan informasi tentang dampak dan bagaimana cara membujuk pengunjung untuk datang berkunjung ke Hypermart. Lima orang informan merupakan staf departemen manager dan EDP yang mengetahui sales di Hypermart.

Seperti yang telah diungkapkan sebelumnya bahwa peningkatan pengujung banyak terjadi pada ibu rumah tangga. Hal ini disebabkan oleh kebutuhan yang ada di rumah tangga, dimana semakin hari tingkat kebutuhan semakin meningkat. Selain itu, promosi yang diterapkan oleh hypermart juga bisa menarik pengunjung untuk datang ke hypermart.

\begin{tabular}{|l|l|l|l|}
\hline No & \multicolumn{1}{|c|}{ Nama } & Umur & Keterangan \\
\hline & Gita & 30 th & Pengunjung \\
\hline & Elly Yanti & 45 th & Pengunjung \\
\hline & Juli & 32 th & Pengunjung \\
\hline
\end{tabular}




\begin{tabular}{|l|l|l|l|}
\hline & Evi & 29 th & Pengunjung \\
\hline $\begin{array}{l}\text { Andest } \\
\text { Putra }\end{array}$ & 28 th & $\begin{array}{l}\text { Staf } \\
\text { Hypermart }\end{array}$ \\
\hline & Supriyadi & 25 th & $\begin{array}{l}\text { Staf } \\
\text { Hypermart }\end{array}$ \\
\hline & $\begin{array}{l}\text { Irwan } \\
\text { Supriyadi }\end{array}$ & 25 th & $\begin{array}{l}\text { Staf } \\
\text { Hypermart }\end{array}$ \\
\hline
\end{tabular}

\section{HASIL PENELITIAN DAN PEMBAHASAN Hasil Penelitian}

Pengukuran peningkatan pengunjung melalui iklan di harian Rakyat Bengkulu dilakukan dengan pendekatan EPIC Model yang bertujuan untuk mengetahui bagaimana peningkatan pengunjung pada Hypermart melalui iklan di harian rakyat bengkulu. Penelitian dilakukan untuk mendapatkan nilai empathy, persuasi, impact dan communication dari pengunjung hypermart di harian rakyat Bengkulu.

\section{Empathy}

Durianto (2003) mengatakan bahwa empati merupakan keadaan mental yang membuat seorang mengidentifikasikan dirinya atau merasa dirinya pada perasaan atau pikiran yang sama dengan orang atau kelompok lain. Konsumen bisa merasakan empat tipe respon afektif yaitu emosi, perasaan khusus, dan evaluasi, penilaian positif atau negatif. Sedangkan kognisi mengacu pada proses mental dan struktur pengetahuan yang dilibatkan dalam tanggapan seseorang terhadap lingkungannya. Aspek kognisi meliputi proses berpikir, sadar, tak sadar, otomatis.

Dalam penelitian ini peneliti mewawancarai informan tentang tanggapan mereka terhadap iklan yang dimuat diharian rakyat bengkulu yang diterapkan oleh Hypermart. Berikut kutipan wawancara penulis dengan ibu Gita.

"hmm...aku taunyo promosi minyak tuh la setiap hari jumat, sabtu kek minggu yo promosi koran tuh lah,dak tau koran apo pokok nyo promosi di koran." (wawancara, 17 juli 2015).

Kemudian ibu Gita meneruskan bahwa menurutnya dengan adanya iklan yang dimuat di harian Rakyat Bengkulu memberi dampak positif, seperti pernyataannya berikut ini:

"yaa promosi yang ado dikoran bagus (positif) karena membantu kito yang kalangan bawah, kayak promosi minyak kan murah lebih hemat" (wawancara, 17 juli 2015).

Hal serupa juga diutarakan oleh ibu Elly Yanti, beliau mengatakan:

"aku merasa senang dengan promo yang ada di koran karena dapat membantu keuangan apalagi aku butuh barang yang banyak untuk dijual kembali untuk toko sendiri jadi perlu yang namanya membeli barangbarang yang promosinya banyak, jadi disini stok barangnya juga lengkap dan sangat memberi dampak yang positif"'(wawancara, 17 juli 2015).

Pernyataan yang sama juga di jelaskan oleh ibu Juli, informan yang ketiga ia mengatakan bahwa:

"aku senang dengan promosi koran terutama promosi kebutuhan kebutuhan dapur seperti minyak goreng. Dan menurut ku promosi koran sangat memberi dampak yang positif, semua pengunjung disini mungkin mencari barang-barang yang promo" (wawancara, 17 juli 2015).

Selain dari tiga informan itu, hal yang sama juga disampaikan oleh informan keempat dengan ibu Evi, ia menjelaskan bahwa:

"Kalau bisa setiap hari saja promosinya jangan Cuma di hari jum'at, sabtu dan minggu biar kami merasa senang merasa terbantu itung-itung menghemat uang belanja. kalau menurut ku semua orang yang datang kesini pasti mengincar barang 
yang sedang promosi itu artinya iklan yang ada diharian rakyat bengkulu sangat positif dan bagus", (wawancara, 17 juli 2015).

Dari hasil wawancara di atas tentang tanggapan informan terhadap iklan yang dimuat di harian Rakyat Bengkulu bahwa promo iklan koran diharian rakyat bengkulu memberi dampak yang baik bagi pengunjung, karena dengan adanya iklan diharian rakyat bengkulu pengunjung dapat mengetahui produ-produk apa saja yang sedang diskon serta pengunjung juga mengetahui produk apa saja terbaru di hypermart.

\section{Persuasi}

Persuasi adalah perubahan kepercayaaan, sikap, dan keinginan berperilaku yang disebabkan suatu komunikasi promosi. Pada penelitian ini peneliti mewawancarai informan staf departement manager frontend bapak Andest Putra tentang bagaimana Hypermart mempengaruhi kepercayaan pengunjung sehingga mereka tertarik untuk mengetahui iklan yang di muat diharian rakyat bengkulu. Menurutnya:

"dengan cara melampirkan produkproduk yang sesuai kebutuhan pengunjung seperti bahan - bahan pokok yang menjadi kebutuhan sehari-hari. Serta harga yang jauh lebih murah dibanding kompetitor atau tempat lain. Dan ia yakin ketika pengunjung mengetahui promosi yang ada diiklan harian rakyat bengkulu pengunjugnakan akan tertarik dan berkunjung ke hypermart " (wawancara, 17 juli 2015).

Penyataan ini kemudian dibenarkan oleh bapak Irwan Supriyadi, informan kedua ia mengatakan:

"menurut saya dengan cara menjelaskan penggunaan /manfaat suatu barang contohnya produkproduk terbaru yang masuk ke hypermart seperti kunci stang mobil, yang kebanyakan pengunjung belum mengetahui bagaimana cara penggunaanya kemudian memberikan informasi tentang diskon-diskon yang menarik sehigga pengunjung tertarik untuk berkunjung ke hypermart."

Informan ini juga menambahkan:

"bahwa ia yakin dan percaya pengunjung akan tertarik berkunjung dan bebelanja ke hypermart" (wawancara, 17 juli 2015).

Hal yang sama dijelaskan oleh bapak Musimin, informan ketiga ia mengatakan :

"selain kita melampirkan produkproduk terbaru, memberikan banyak diskon serta menjelaskan manfaat atau pengguna barang kita juga perlu memperhatikan ketersediaan barang. Karena percuma saja banyak promosi tetapi barang tidak tersedia diarea itu tidak akan bisa meningkatkan pengunjng".

Ia juga mengatakan :

"selain itu yang terpenting adalah bagaimana pelayanan juga penyampaian promosi yang ada di iklan harian rakyat bengkulu terhadap pengunjung, menurutnya yakin dan percaya aja pengunjung tertarik”. (wawancara, 17 juli 2015).

Dari pernyataan ketiga informan tersebut, untuk meningkatkan pengunjung, hypermart perlu melakukan beberapa hal diantaranya melampirkan produk-produk yang berkualitas serta informasi diskon yang jauh lebih murah, sehingga pengunjung akan tertarik untuk selalu berkunjung ke hypermart.

Selain melakukan promosi, mempersiapkan stock barang ditoko juga berpengaruh terhadap peningkatan pengunjung. Pengunjung tidak akan berkunjung kehypermart apabila stock barang tidak tersedia. 


\section{Impact / dampak}

Dimensi Impact menunjukkan apakah suatu merek dapat terlihat menonjol dibandingkan merek lain pada kategori serupa dan apakah iklan mampu menarik perhatian konsumen dalam pesan yang disampaikan. Dampak yang diinginkan dari hasil iklan adalah jumlah pengetahuan produk (product knowledge) yang dicapai konsumen melalui tingkat keterlibatan (involvement) konsumen dengan produk atau proses pemilihan.

Penelitian kali ini peneliti hanya mewawancarai satu informan dari staf hypermart yaitu bapak Supriyadi departemen manager groceris non food tentang tingkat kelas atau kualitas produk, bentuk produk, merek serta harga yang dimuat di harian rakyat bengkulu. Bapak Supriyadi menjelaskan:

"bahwa produk-produk yang ada di hypermart merupakan produk dengan kualitas sangat terjamin. Bentuknya bisa berupa kebutuhan primer, sekunder serta tersier sesuai kebutuhan masyarakat bengkulu. Merek-merek nya pun yang ternama serta mengikuti perkembangan zaman sehingga dapat meyakinkan pengunjung selain itu harganya pun sesuai dengan harga yang dipromosikan di iklan harian rakyat Bengkulu” (wawancara, 17 juli 2015). Ditempat yang bersamaan, hal serupa juga diutarakan oleh dua informan yaitu bapak musimin dan bapak irwan supriyadi, mereka mengatakan:

"ya untuk meyakin pengunjung kita perlu memberikan produk-produk yang berkualitas, barang-barang yang bagus dan menarik dan harganya pun sudah pasti sesuai dengan harga yang dipromosikan”. (wawancara, 17 juli 2015).

Dari analisis dengan beberapa informan tentang tingkat kualitas, bentuk produk, merek serta harga yang dimuat diiklan harian rakyat bengkulu dapat di jelaskan bahwa semua produk yang di promosikan sesuai dengan apa yang di muat di iklan harian rakyat bengkulu.

\section{Communication}

Dimensi komunikasi memberikan informasi tentang kemampuan konsumen dalam mengingat pesan utama yang disampaikan, pemahaman konsumen, serta kekuatan kesan yang ditinggalkan pesan tersebut. Peneliti mewawancarai informan yang pertama dengan ibu Gita yang berkunjung ke hypermart tentang bagaimana pemahaman penyampaian informasi iklan harian rakyat bengkulu, serta pesan dan kesan setelah mengetahui adanya iklan yang dimuat diharian rakyat bengkulu. Berikut kutipan wawancara peneliti dengan ibu gita,

"sebenarnyo aku kurang tau promosi koran karena aku nggak berlangganan koran, aku juga kurang tau koran apa yang dimaksud. Sepengetahuan aku yang promosi itu yo setiap hari jum'at, sabtu dan minggu. Pesan aku sih sering-sering aja promosinya jadikan kita lebih hemat uang belanjo". (wawancara, 17 juli 2015)

Pernyataan berbeda pun diutarakan oleh informan kedua dengan ibu Elly Yanti, berikut kutipannya:

"kalau aku tidak berlanggan koran rakyat bengkulu tapi aku tau promosi koran yang berlangsung setiap hari jum 'at, sabtu dan minggu karena aku selalu mengunjungi hypermart untuk membeli semua produk diskon yang ada di hypermart utuk dijual kembali. Namun tidak semua produk yang diskon dapat aku beli semuanya karena bagi pengunjung yang membeli dan untuk dijual kembali dari hypermart membatasi penjualannya hal ini untuk memberi 
kesempatan kepada pengunjung lain untuk membeli barang diskon. Yaa walaupun dibatasi aku tetap membeli seberapa mampunya. Pesan aku yaa jangan dibatasi barangnya dan promosinya juga harus lebih banyak lagi”. (wawancara, 17 juli 2015)

Selain Pertanyaan dari informan kedua, informan ketiga pun memberikan komentarnya dengan ibu Juli, berikut komentarnya :

" aku tidak berlangganan koran harian rakyat bengkulu tapi aku tau promosi koran yang berlangsung setiap weekend, yaa walaupun tidak berlangganan tapi aku selalu mengikuti setiap weekend aku juga selalu berkunjung ke hypermart untuk membeli kebutuhan rumah tanggaku. Promosinya banyak sekali terkadang aku secara otomatis/ secara tidak langsung mengambil barang-barang yang sedang promosi tanpa pikir panjang lagi". (wawancara, 17 juli 2015)

Ia juga mengatakan :

"Kalau bisa promosinya dikomunikasikan lagi jangan Cuma lewat koran saja, apalagi aku, akukan tidak berlangganan koran harian rakyat bengkulu jadi kalau aku tidak berkunjung ke hypermart setiap weekend mungkin aku tidak tau”. (wawancara, 17 juli 2015)

Dan selanjutnya pernyataan dari informan keempat dengan ibu Evi, berikut kutipan wawancara peneliti dengan informan :

"menurutku promosi koran jangan hanya dikoran harian rakyat bengkulu saja, kan masih banyak koran lainnya seperti bengkulu expres, jadi kita tidak terpaku pada koran yang satu saja. Seperti aku terkadang aku tidak membaca koran harian rakyat bengkulu itu artinya aku tidak mengetahui promosi apa saja yang ada di iklan harian rakyat bengkulu. Dan selebihnya promosinya sangat menarik semua sesuai dengan kebutuhan masyarakat bengkulu, termasuk saya”. (wawancara, 17 juli 2015)

Dari hasil wawancara dengan beberapa informan dapat dijelaskan bahwa sebagian pengunjung hanya mengetahui promosi yang berlangsung setiap weekend dan hanya sebagian saja yang mengetahui promosi iklan yang ada diharian rakyat bengkulu, padahal promo yang berlangsung di weekend merupakan promo yang ada di iklan diharian rakyat Bengkulu. Serta, kurangnya pengunjung yang berlangganan koran harian rakyat bengkulu sehingga kurang juga dengan promosi-promosi diiklan harian harian rakyat bengkulu.

\section{Pembahasan}

Berdasarkan hasil penelitian yang dilakukan peneliti kepada informan, dapat dilihat bahwa dalam kegiatan penjualan untuk dapat menigkatkan jumlah pengunjung peneliti menganalisis dari teori EPIC dimana hasil penelitian menunjukkan bahwa dalam peningkatan jumlah pengunjung diperlukan:

\section{Empathy}

Durianto (2003) empati merupakan keadaan mental yang membuat seorang mengidentifikasikan dirinya atau merasa dirinya pada perasaan atau pikiran yang sama dengan orang atau kelompok lain. Konsumen bisa merasakan empat tipe respon afektif yaitu emosi, perasaan khusus, dan evaluasi, penilaian positif atau negatif. Sedangkan kognisi mengacu pada proses mental dan struktur pengetahuan yang dilibatkan dalam tanggapan seseorang terhadap lingkungannya. Aspek kognisi meliputi proses berpikir, sadar, tak sadar, otomatis.

Berdasarkan hasil penelitian, pengunjung merasa sadar ketika mereka berbelanja ke hypermart. Ada juga beberapa 
pengunjung yang tidak sadar ketika berbelanja, hal ini dikarenakan pengunjung tidak mengetahui bahwa mereka berbelanja di hari weekend sehingga mereka tidak menyadari bahwa mereka membeli produkproduk diskon.

Setelah membaca iklan yang ada di harian rakyat bengkulu atau mengetahui ada diskon/promo, ada beberapa pengunjung yang secara otomatis langsung berbelanja namun ada juga yang menunda karena hal tertentu. Dari wawancara dengan beberapa informan mereka mengatakan bahwa promosi atau iklan yang ada di harian rakyat bengkulu dapat membantu keuangan mereka, mereka juga memberikan tanggapan yang positif.

\section{Persuasi}

Persuasi adalah perubahan kepercayaaan, sikap, dan keinginan berperilaku yang disebabkan suatu komunikasi promosi. Dari hasil penelitian peneliti dengan informan, mereka melampirkan produk-produk yang murah serta diskon yang besar dibanding kompetitor lainnya. Selain itu mereka juga memperhatikan stok barang di area agar pengunjung tidak kesulitan mencari barang kebutuhan mereka. Menjelaskan penggunaan produk juga sangat penting karena berpengaruh pada pengunjung jika pengunjung tidak mengetahui manfaat atau cara penggunaan barang tentu mereka kecewa dengan hypermart hal ini berpengaruh pada peningkatan pengunjung.

\section{Impact}

Dimensi Impact menunjukkan apakah suatu merek dapat terlihat menonjol dibandingkan merek lain pada kategori serupa dan apakah iklan mampu menarik perhatian konsumen dalam pesan yang disampaikan. Dampak yang diinginkan dari hasil iklan adalah jumlah pengetahuan produk (product knowledge) yang dicapai konsumen melalui tingkat keterlibatan (involvement) konsumen dengan produk atau proses pemilihan. Menurut mereka tingkat kualitas yang dijual dihypermart merupakan kualitas terbaik, baik dari segi bentuk barang, merek barang, jenis barang, serta harga yang sesuai dengan tingkat pendapatan masyarakat bengkulu. Selain itu pelayanan yang terbaik dari hypermart juga mereka utamakan.

\section{Communication}

Dimensi komunikasi memberikan informasi tentang kemampuan konsumen dalam mengingat pesan utama yang disampaikan, pemahaman konsumen, serta kekuatan kesan yang ditinggalkan pesan tersebut. Hasil penelitian dari informan mereka sangat tertarik dengan adanya promosi diiklan harian rakyat bengkulu, mereka mengatakan sangat senang dengan promosi yang diada di iklan harian rakyat bengkulu. Selain itu ada beberapa pengunjung yang kurang mengetahui promosi koran Harian Rakyat Bengkulu, mereka hanya mengetahui promosi yang terjadi di setiap akhir pekan yaitu setiap hari jum'at, sabtu dan minggu saja. Ada juga yang mengatakan jika promosi koran diHarian Rakyat Bengkulu hanya terpaku pada satu jenis koran saja jadi mereka kurang mengetahui apa saja yang di promosikan apalagi mereka yang tidak berlangganan koran harian rakyat bengkulu. Hal ini dapat mengurangi tingkat pengunjung untuk datang ke Hypermart.

Berdasarkan teori EPIC pada hasil penelitian penulis, dapat dijelaskan bahwa comunnication pada teori EPIC kurang sesuai dengan hasil penelitian ini dikarenakan komunkasi dengan media massa seperti koran belum efektif karena banyak pengunjung hypermart yang tidak berlangganan koran. Sehingga pengunjung kurang mengetahui adanya promosi yang ada diiklan harian rakyat bengkulu. Kurang adanya komunikasi yang efektif inilah yang menjadi penghambat sehingga pengunjung hanya mengetahui iklan 
yang terjadi pada weekend atau pada hari jum'at, sabtu dan minggu selain itu, pengunjung hanya mengetahui iklan promosi minyak, dan promosi yang dijalankan hanya menggunakan satu jenis koran saja yaitu iklan di Harian Rakyat Bengkulu.

\section{PENUTUP}

\section{Kesimpulan}

Berdasarkan hasil pembahasan diatas, penulis menarik kesimpulan sebagai berikut:

1. Dengan adanya promosi Iklan harian Rakyat Bengkulu, Hypermart perlu melakukan diskon yang jauh lebih murah, sehingga pengunjung akan tertarik untuk selalu berkunjung ke hypermart.

2. Dari sisi Peningkatan Pengunjung Iklan di Harian Rakyat Bengkulu merupakan media massa yang sangat membantu dalam memberikan informasi tentang produk-produk yang sedang dipromosikan di Hypermart.

3. Dari segi communication pada Iklan di Harian Rakyat Bengkulu yang dilakukan oleh Hypermart dalam melakukan promosi dianggap belum maksimal ini dikarenakan adanya pengunjung yang tidak berlangganan Koran Harian Rakyat Bengkulu sehingga untuk meningkatkan pengunjung belum maksimal.

4. Dampak dari hasil Iklan Harian Rakyat Bengkulu yang diterapkan oleh Hypermart adalah hanya sebagian pengunjung yang mengetahui adanya promosi koran iklan di Harian Rakyat Bengkulu.

\section{Saran}

Dari hasil penelitian ini, dapat dikemukakan beberapa saran diantaranya:

1. Perusahaan perlu memperhatikan komunikasi agar promo-promo yang tertera di iklan harian rakyat bengkulu dapat di ketahui oleh pengunjung.

2. Letak posisi barang harus sesuai dengan label harga yang tertera sehingga pengunjung tidak merasa kesulitan pada saat berkunjung ke Hypermart.

3. Penyampaian promosi melalui custumer service harus jelas dan mudah dimengerti oleh pengunjung agar tidak terjadinya komplain pada saat transaksi.

4. Pelayanan terhadap pengunjung perlu diperhatikan agar pengunjung merasa nyaman dan terbantu.

\section{DAFTAR PUSTAKA}

Durianto, Sugiarto, Widjaja dan Supraktino. (2003). Invasi Pasar Dengan Iklan Yang Efektif. Jakarta: Gramedia Pustaka Utama.

Lukman, Syamsudin. (2007). Manajemen Keuangan Perusahaan. Jakarta: Raja Grafindo Persada.

Moleong, Lexy. (2002). Metodologi Penelitian Kualitatif. Bandung: PT. Remaja Rosdakarya.

Muchtar, Suriadi. (2010). Iklan Sebagai Sarana Promosi Paling Efektif. Jakarta: Graha Ilmu.

Subagyo, P. Joko. (2011). Metode Penelitian. Jakarta: PT. Rineka Cipta.

Sugiyono, (2008). Metode Penelitian Kuantitatif Kualitatif dan $R \& D$. Bandung: Alfabeta.

Patton, MQ. (2011). Metode Evaluasi Kualitatif. Jakarta: Pustaka Pelajar.

Widodo, Elli. (2011). Iklan dan Pengaruhnya Terhadap Kuantitas Penjualan Produk/Jasa. Jakarta: Media Computindo. 